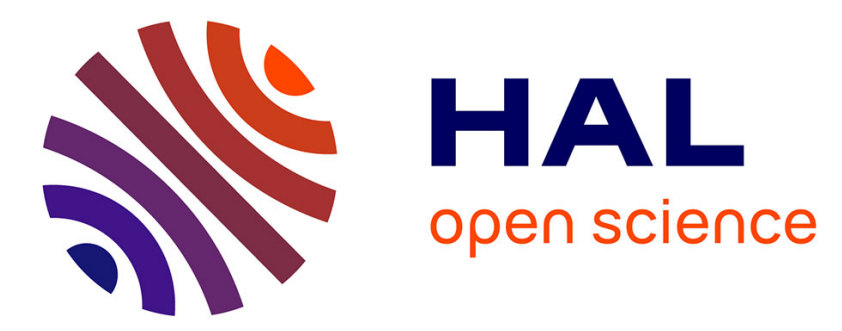

\title{
1D continuous gel electrophoresis composition for the separation of deamidated proteins
}

Axel Boudier-Lemosquet, Adrien Mahler, Claude Bobo, Violaine Moreau, Muriel Priault

\section{- To cite this version:}

Axel Boudier-Lemosquet, Adrien Mahler, Claude Bobo, Violaine Moreau, Muriel Priault. 1D continuous gel electrophoresis composition for the separation of deamidated proteins. Methods, 2021, 10.1016/j.ymeth.2021.03.002 . hal-03408329

HAL Id: hal-03408329

https://cnrs.hal.science/hal-03408329

Submitted on 29 Oct 2021

HAL is a multi-disciplinary open access archive for the deposit and dissemination of scientific research documents, whether they are published or not. The documents may come from teaching and research institutions in France or abroad, or from public or private research centers.
L'archive ouverte pluridisciplinaire HAL, est destinée au dépôt et à la diffusion de documents scientifiques de niveau recherche, publiés ou non, émanant des établissements d'enseignement et de recherche français ou étrangers, des laboratoires publics ou privés. 


\title{
1D continuous gel electrophoresis composition for the separation of deamidated proteins
}

\author{
Axel Boudier-Lemosquet ${ }^{\mathrm{a}, 1}$, Adrien Mahler ${ }^{\mathrm{a}, 1}$, Claude Bobo $^{\mathrm{a}}$, Violaine Moreau ${ }^{\mathrm{b}}$, \\ Muriel Priault ${ }^{\mathrm{a}, *}$ \\ ${ }^{a}$ Univ. Bordeaux, CNRS, IBGC, UMR 5095, F-33000 Bordeaux, France \\ ${ }^{\mathrm{b}}$ Univ. Bordeaux, INSERM BaRITOn, U1053, F-33000 Bordeaux, France
}

\section{A R T I C L E I N F O}

\section{Keywords:}

Denaturing electrophoresis

Separation of deamidated proteins

Buffer formulation

Protein stability

Bcl-xL

Calmodulin

RhoA

Rac1

Cdc42

\begin{abstract}
A B S T R A C T
Deamidation is a spontaneous modification of peptides and proteins that has potent repercussions on their activity and stability in vivo and in vitro. Being able to implement easy techniques to detect and quantify protein deamidation is a major goal in this field. Here we focus on electrophoretic methods that can be deployed to assess protein deamidation. We provide an update on the use of Taurine/Glycinate as trailing ions to assist the detection of several examples of deamidated proteins, namely the small GTPases RhoA, Rac1 and Cdc42, but also the oncogene Bcl-xL and calcium-binding Calmodulin. We also report on the use of imidazole as a counter ion to improve the focusing of deamidated bands. Finally, we provide examples of how these gels proved useful to compare on full-length proteins the effect of ions and $\mathrm{pH}$ on the catalytic rates of spontaneous deamidation.

Taken together, the electrophoretic method introduced here proves useful to screen at once the effect of various conditions of $\mathrm{pH}$, ionic strength and buffer ions on protein stability. Direct applications can be foreseen to tailor buffer formulations to control the stability of proteins drug products.
\end{abstract}

\section{Introduction}

Deamidation is the epitome of time-related chemical instability that is inherent to some amino acids in peptides and proteins. Under physiologic conditions, spontaneous degradation of Asparaginyl (Asn) and Glutaminyl (Gln) residues happens with time, as an intra-molecular rearrangement leads the lateral chain to lose the amino-group. These two neutral polar residues are thus converted into their acidic derivatives: Aspartyl (Asp) and Glutaryl (Glu) residues respectively when the conventional peptide chain is maintained; $\beta$-Aspartyl (IsoAsp) and $\gamma$-Glutaryl (IsoGlu) residues are also produced when the intra-molecular rearrangement leads to the incorporation of $\mathrm{C} \beta$ or $\mathrm{C} \beta$ and $\mathrm{C} \gamma$ respectively in addition to $\mathrm{C} \alpha$ in the peptide chain. Such beta-linked or gamma-linked residues lengthen the backbone of the protein respectively by one or two carbon units and are described to be potent structural/functional modifiers $[1,2]$.

Deamidation produces a permanent alteration of the protein sequence compared to its time of synthesis, and only neo-synthesis can restore the original protein. At physiological $\mathrm{pH}$, deamidation introduces a negative charge that, together with the kink imparted by beta-linked IsoAsp or gamma-linked IsoGlu residues, may alter the protein original folding and hence its activity, stability, or aggregation. In biology, deamidation is therefore mostly considered as a process disrupting normal functions, which is substantiated by the fact that deamidation is associated with age-related diseases like Parkinson disease [3,4], Alzheimer's disease [5] and cataract [6,7]. But the outreach of deamidation is beyond biology, and if Asn deamidation has become a concern for the stability of protein drug products engineered by biotechnology companies (for example, a single IsoAsp can cripple the entire antigen binding region), Gln deamidation is of interest in fields like forensics (for the dating of fingerprints), or art and archaeology (for the dating of paintings or bones) (see references in this special issue of Methods).

Regarding the mechanism involved, deamidases are found in bacteria and viruses, where deamidation is thus deployed in the array of enzyme-catalyzed post-translational modifications to convey signal transduction (see $[8,9]$ for reviews); but eukaryotes seem to be devoid of such enzymes, and deamidation is considered to occur by a spontaneous

\footnotetext{
* Corresponding author.

E-mail address: muriel.priault@ibgc.cnrs.fr (M. Priault).

1 Equal contribution.
} 
reaction in this realm. Deamidation rate values determined on pentapeptides at $\mathrm{pH}=7.4,37.0^{\circ} \mathrm{C}, 150 \mathrm{mM}$ Tris- $\mathrm{HCl}$ buffer showed that $\mathrm{Gln}$ deamidation is much slower than that of Asn (the fastest Gln deamidation has a half-life of $\sim 2$ years, while Asn deamidation has a half-life of $\sim 1$ day) [10]. Asn deamidation has thus readily been documented in hundreds of proteins or naturally occurring peptides [11], while Gln deamidation has essentially been reported in very long-lived proteins such as the eye crystallins [7] or brain proteins. Nevertheless, both are biologically significant, despite the emphasis set on Asn deamidation.

All Asn and Glu in proteins or peptides are not equally susceptible to deamidation. The probability increases if the $n+1$ amino acid offers a low steric hindrance. This concept has been established on short Asn- or Gln- containing peptides, of which the sequences were selected from proteins known to deamidate (aldolase, calmodulin, cytochrome $c$, lysozyme, ribonuclease $\mathrm{A}$, and triosephosphate isomerase, to name but a few). An extensive compiling work by the Robinson lab and by the Aswad lab has evaluated how the values measured on peptides more or less accurately matched those on whole proteins [12,13]. Model peptides where thus instrumental to determine the dependence of deamidation rate on the primary structure; their use was also key to address the role of temperature, $\mathrm{pH}$ and ionic strength on deamidation rates [14-18].

Separating non deamidated and deamidated species is technically challenging, as each deamidation reaction produces only minor changes in the parameters commonly used to discriminate proteins: the $-\mathrm{NH}_{2}$ to -OH modification only causes a 0.984 Da mass increase, and at physiological $\mathrm{pH}$, the carboxylic acid derivatives formed after deamidation add one negative charge. But deamidation does not modify the hydropathy index. Resolving these subtle changes requires high precision methods, and mass spectrometry is considered best suited because of the accuracy it provides. Still, other methods can prove very helpful in first intention, if they compensate a lesser accuracy by higher throughput, faster analysis, lower cost, and equipment/skills that are commonly available in laboratories. Routine denaturing gel electrophoresis (distinct from capillary gel electrophoresis or native gels electrophoresis which have also been successfully used in deamidation analyses $[19,20])$ certainly meets these criteria and various compositions have already been proposed to assist the detection of deamidated proteins. The Lubec lab for example described the combination of in situ V8 digestion of proteins and orthogonal analysis on native PAGE followed by SDS-PAGE to visualize differences in electrophoretic mobilities in deamidated versus non deamidated proteins [21]. Our lab also successfully implemented the combination of native PAGE and SDS-PAGE to detect Asn deamidation (see suppl Fig. S2 in [22]). But these methods rely on multi-step analyses and to overcome this drawback, we recently described a modified electrophoretic method using Taurine/Glycinate as trailing ions to allow, on mini-gels, a fast and accurate detection of the sequential deamidation of Asn52 and Asn66 in Bcl-xL [23].

Here, we show that Gln deamidation can also be monitored with the same mini-gels, using the small GTPases RhoA, Rac1 and Cdc42 as model proteins. We also describe a new PAGE setup where we added imidazole as a counter ion in the stacking gel, to further improve the focusing of deamidated bands of two other poly-deamidable proteins: Bcl-xL and Calmodulin. Finally, we show how the use of such gels was instrumental to compare the effect of ions and $\mathrm{pH}$ on the deamidation rates of Bcl-xL and Calmodulin, and compare how different buffer formulations affect the catalytic rate of deamidation.

\section{Material and methods}

\subsection{Cell culture}

HCT116 cells were grown in OptiMEM medium (Gibco). 800,000 cells were plated onto $6 \mathrm{~cm}$ dishes and left to adhere overnight. The following day, $8 \mathrm{nM}$ or $16 \mathrm{nM}$ of recombinant GST-CNF1 or the equivalent vehicle (DMSO) were added for $16 \mathrm{~h}$ or $24 \mathrm{~h}$, along with $20 \mu \mathrm{M}$
MG132 (Z-Leu-Leu-Leu-al, Sigma) to inhibit proteasomal degradation.

\subsection{Total proteins extraction}

HCT116 cells were harvested and the pellets were resuspended in RIPA buffer (1\% NP-40, 0.5\% sodium-deoxycholate, 0.1\% SDS in PBS, supplemented with proteases inhibitor Mini ${ }^{\circledR}$ (Roche Diagnostics)) for $20 \mathrm{~min}$ on ice. The solubilized proteins were then recovered in the supernatant after a 20 min-centrifugation at $12,000 \mathrm{~g}$.

\subsection{Recombinant proteins}

Cytotoxic necrotizing factor 1 (CNF1) was expressed by BL21 $E$. coli strain from the pGEX-CNF1 plasmid, which was a generous gift of Dr. Jacques Bertoglio (Villejuif, France). GST-CNF1 was expressed and purified as previously described [24]. The molar extinction coefficient of the fusion protein was calculated by ProtParam (Expasy) and the protein concentration determined to be $41 \mu \mathrm{M}$. The quality of the purified protein was assessed by SDS-PAGE, and its activity was estimated using its ability to induce podosomes and multinucleation in endothelial cells as previously described [25].

Human recombinant Calmodulin was purchased from Enzo Life Sciences (BML-SE325-0001).

Full length human Bcl-xL was expressed from pnYC plasmid [26] in E. coli BL21DE3 strain as described in [27]. Briefly, IPTG (Isopropyl $\beta$-D1-thiogalactopyranoside) was used to induce the protein expression for $3 \mathrm{~h}$ at $37^{\circ} \mathrm{C}$. Cells were harvested and lysed by sonication in $25 \mathrm{mM}$ Tris$\mathrm{HCl} \mathrm{pH}=8,100 \mathrm{mM} \mathrm{NaCl}, 2 \mathrm{mM} \mathrm{MgCl} 2$ supplemented with $0.1 \mathrm{mg} / \mathrm{mL}$ DNase I and proteases inhibitors. After centrifugation $(20 \mathrm{~min}$ at 16 $000 \mathrm{~g}$ ), the pellet was resuspended in $6 \mathrm{M}$ urea, $2 \mathrm{mM}$ DTT (Dithiothreitol), $1 \mathrm{mM}$ EDTA, $20 \mathrm{mM}$ Tris- $\mathrm{HCl} \mathrm{pH}=8$ to retrieve Bcl-xL from inclusion bodies. Insoluble material was removed by centrifugation while the supernatant was injected on a Superdex $75-16 / 600 \mathrm{Gel}$ Filtration column (flow rate $1 \mathrm{~mL} / \mathrm{min}$ ) with $150 \mathrm{mM} \mathrm{NaCl}, 25 \mathrm{mM}$ Tris$\mathrm{HCl} \mathrm{pH}=8$ as mobile phase. The peak of interest was then loaded on a HiTrap Q HP anion exchange column (flow rate $0.4 \mathrm{~mL} / \mathrm{min}$ ) and $\mathrm{Bcl}-\mathrm{xL}$ eluted with a linear $150 \mathrm{mM}-1 \mathrm{M} \mathrm{NaCl}$ salt gradient. Mass spectrometry was used to ensure that the full length protein had been purified, as expression from bacteria was previously shown to lead to possible Cterminal proteolysis of Bcl-xL [28].

Table 1

Composition, $\mathrm{pH}$ and ionic strength of the deamidation solutions.

\begin{tabular}{|c|c|c|c|}
\hline & & $\begin{array}{l}\text { Ionic } \\
\text { strength }\end{array}$ & $\begin{array}{l}\text { Measured } \\
\mathrm{pH}\end{array}$ \\
\hline \multirow[t]{6}{*}{ Bcl-xL(1 ng/ $\mu \mathrm{L}$ final) } & $\begin{array}{l}\text { Stock solution } \\
(25 \mathrm{mM} \text { Tris, } 450 \mathrm{mM} \\
\mathrm{NaCl})\end{array}$ & 0,45 & 8 \\
\hline & $\begin{array}{l}\text { Stock solution }+50 \mathrm{mM} \\
\text { Phosphate }\end{array}$ & 0,56 & 9 \\
\hline & $\begin{array}{l}\text { Stock solution }+100 \mathrm{mM} \\
\mathrm{NH}_{4} \mathrm{OH}\end{array}$ & 0,45 & 10 \\
\hline & $\begin{array}{l}\text { Stock solution }+50 \mathrm{mM} \\
\text { Tris }\end{array}$ & 0,45 & 8,5 \\
\hline & $\begin{array}{l}\text { Stock solution }+25 \mathrm{mM} \\
\text { Glycine }\end{array}$ & 0,44 & 8,6 \\
\hline & $\begin{array}{l}\text { Stock solution }+50 \mathrm{mM} \\
\mathrm{NaOH}\end{array}$ & 0,46 & 8 \\
\hline \multirow[t]{5}{*}{$\begin{array}{l}\text { Calmodulin (100 ng/ } \\
\mu \mathrm{L} \text { final) }\end{array}$} & $\begin{array}{l}\text { Stock solution } \\
(10 \mathrm{mM} \mathrm{MES}, 500 \mathrm{mM} \\
\mathrm{NaCl})\end{array}$ & 0,50 & 6,7 \\
\hline & $\mathrm{H}_{2} \mathrm{O}+50 \mathrm{mM}$ Phosphate & 0,21 & 11 \\
\hline & $\mathrm{H}_{2} \mathrm{O}+100 \mathrm{mM} \mathrm{NH}_{4} \mathrm{OH}$ & 0,10 & 10 \\
\hline & $\mathrm{H}_{2} \mathrm{O}+50 \mathrm{mM}$ Tris & 0,07 & 8,5 \\
\hline & $\mathrm{H}_{2} \mathrm{O}+50 \mathrm{mM} \mathrm{NaOH}$ & 0,08 & 10 \\
\hline
\end{tabular}




\subsection{Chemical deamidation of recombinant proteins}

The solutions tested are listed in Table 1. Ionic strength is calculated as follows: $I=1 / 2 \sum_{i} c_{i} z_{i}^{2}$ with $c_{i}=$ concentration of the $\mathrm{i}^{\text {th }}$ ion; $\mathrm{z}_{\mathrm{i}}=$ charge of the $i^{\text {th }}$ ion.

Human recombinant Calmodulin was resuspended in $10 \mathrm{mM}$ MES (2(N-morpholino)ethanesulfonic acid) $\mathrm{pH}=6.7$ containing $500 \mathrm{mM} \mathrm{NaCl}$. A total amount of $5 \mu \mathrm{g}$ of protein was exposed to the indicated solutions (final volume $50 \mu \mathrm{L}$ ) for various durations at $37{ }^{\circ} \mathrm{C}$. Each solution contained either $1 \mathrm{mM} \mathrm{CaCl} 2$ or $1 \mathrm{mM}$ EDTA. A total amount of $1 \mu \mathrm{g}$ was separated on $12 \%$ polyacrylamide gels and stained with Coomassie Blue.

Human recombinant Bcl-xL was stored in $25 \mathrm{mM}$ Tris $\mathrm{HCl} \mathrm{pH}=8$, $450 \mathrm{mM} \mathrm{NaCl}$. A total amount of $250 \mathrm{ng}$ of protein was incubated at $37{ }^{\circ} \mathrm{C}$ in various deamidation solutions (final volume $250 \mu \mathrm{L}$ ) supplemented with $10 \mathrm{mM}$ DTT to prevent dimerization. Untreated WT recombinant Bcl-xL was used as the non-deamidated control, while recombinant Bcl-xL N52D/N66D was used as a migration standard for double deamidation as in [23]. $10 \mathrm{ng}$ of proteins were separated on $15 \%$ polyacrylamide gels.

\subsection{Electrophoresis}

In the original mini-gel composition we described in [23], chloride composes the leading phase of high mobility ions while Taurine and Glycinate compose the trailing phase of low mobility ions. The stacking/ destacking of proteins to be separated is ensured by the shift of $\mathrm{pH}$ between the stacking gel $(\mathrm{pH}=6.7)$ and the resolving gel $(\mathrm{pH}=8.8)$, and the change of the pore size from $5 \%$ in the stacking gel to $12 \%$ or $15 \%$ in the resolving gel. Stacking formulation: $125 \mathrm{mM}$ Tris- $\mathrm{HCl} \mathrm{pH}=6.7$ and 5\% acryl/bisacryl 37.5:1. Resolving gel composition: $75 \mathrm{mM}$ Tris, 225 $\mathrm{mM}$ Taurine, $125 \mathrm{mM}$ Glycine, $23 \mathrm{mM} \mathrm{HCl,} 12 \%$ or $15 \%$ acryl/bisacryl 37.5:1.

In the modified mini-gels described here, the same resolving gel as above is used, but the counter ions in the stacking gel are Tris ( $\mathrm{pKa}=$ 8.3) and imidazole ( $\mathrm{pKa}=6.95$ ). The stacking gel formulation is 150 $\mathrm{mM}$ Tris- $\mathrm{HCl} \mathrm{pH}=6.8,200 \mathrm{mM}$ imidazole, $0.1 \%$ SDS.

Gel polymerization is induced by addition of APS $(0.6 \mathrm{mg} / \mathrm{mL})$ and Temed ( $1 \mu \mathrm{L} / \mathrm{mL}$ ). Migration buffer for all the electrophoretic separations was Glycine $327 \mathrm{mM}$, Tris $50 \mathrm{mM}$, SDS $1.5 \mathrm{~g} / \mathrm{L}$. Electrophoresis was performed at $25 \mathrm{~mA}$ per mini-gel.

\subsection{Western blots}

Proteins separated on polyacrylamide gels were transferred onto nitrocellulose membranes (Amersham) and western-blots revealed with Clarity Western ECL (Biorad). Antibodies used are: rabbit anti-Bcl-xL (ab32370, Abcam), rabbit mAb anti-RhoA (67B9, Cell Signaling Technology), rabbit anti-Rac1/2/3 (2465, Cell Signaling Technology), rabbit mAb anti-Cdc42 (11A11, Cell Signaling Technology). Horseradish peroxidase-conjugated secondary antibodies were from Jackson Immunoresearch.

\subsection{IsoAspartate quantification}

The bioluminescent-based IsoQuant-Glo ${ }^{\mathrm{TM}}$ detection kit (Promega) was used according to the manufacturer's instructions. The principle of the assay relies on the ability of the enzyme L-isoaspartyl methyltransferase (PIMT) to catalyze the transfer of a methyl group from Sadenosyl-L-methionine (SAM) onto IsoAsp residues, to produce stoichiometric amounts of S-adenosyl-L-homocysteine (SAH). Coupled reactions further converts SAH into adenosine triphosphate (ATP) which is ultimately quantified using luciferase and luciferin reaction and generating light. Here, $1.54 \mu \mathrm{g}$ of Calmodulin previously submitted to deamidation solutions containing either EDTA or $\mathrm{Ca}^{2+}$ were mixed with 1 mM SAM and $25 \mathrm{ng}$ of PIMT. $30 \mathrm{~min}$ later, the IsoQuant-Glo reagent was added and further incubated for $30 \mathrm{~min}$. Finally, the detection solution was added and luminescence was measured without filter 15 min later on a CLARIOstar (BMG Labtech).

\section{Results}

\subsection{Gln deamidation monitoring on Taurine/Glycinate mini-gels}

We initially designed Taurine/Glycinate gels to assist the separation of Asn deamidated proteins [23]. We set out to determine whether these gels could also be used to separate Gln deamidated proteins. Upon bacterial infection, some proteins of the target cells undergo deamidation. In particular, Cytotoxic Necrotizing Factor 1 (CNF1) secreted by some $E$. coli strains is a bacterial deamidase known to induce the transient activation of the cellular $21 \mathrm{kDa}$ GTPases RhoA, Rac1 and Cdc42 via the deamidation of a unique Glutamine residue (Gln63 in RhoA and Gln61 in Rac1 and Cdc42) [29,30]. Signal transduction is later interrupted by proteasomal degradation of the deamidated GTPases [31]. We treated HCT116 cells for $16 \mathrm{~h}$ and $24 \mathrm{~h}$ with a ramping amount of GSTCNF1 to ensure that the small GTPases would be activated, and in the presence of MG132 to prevent their proteasomal degradation. The use of a $15 \%$ Taurine/Glycinate mini-gels proved efficient to observe a migration shift between native and deamidated RhoA and Rac1 (Fig. 1), while standard SDS-PAGE showed no difference (data not shown). The band shift accompanying Cdc42 deamidation was also visible, however less conspicuous than for RhoA and Rac1. Thus monodeamidation of Gln residues can be resolved by the use of Taurine-Glycinate as trailing ions in mini-gels, at least in the range of $15-40 \mathrm{kDa}$.

\subsection{Imidazole as a counter ion improves the electrofocusing of deamidated proteins}

The use of Taurine/Glycinate as trailing ions allowed us to pioneer the description of the sequential deamidation of the cellular oncogene Bcl-xL [23]. This $26 \mathrm{kDa}$ protein adopts the classical fold characteristic of Bcl-2 family members, namely a globular protein organized in alpha helices. Unlike other proteins of this family, Bcl-xL shows unique eligibility to deamidation on Asn52 and Asn66. These residues are located in a loop that appears unstructured in NMR and X-Ray crystallography [32], and both are followed by a Glycine. Despite the structural resemblance of their local environment, we found that Asn52 is more prone to deamidation than Asn66 in cultured cells and in vivo, and that the obligate deamidation sequence is Asn52 first and Asn66 last [22]. This produces the 52 monodeamidated and the 52/66 doubly deamidated forms of Bcl-xL for which characteristic migration distances can be appreciated on Taurine/Glycinate gels (Fig. 2A).

As described in the literature, the continuous SDS stack that migrates between the leading and the trailing ion in the resolving gel has harmful effects on the resolution of proteins below $40 \mathrm{kDa}$ [33]. Maly et al. described a discontinuous PAGE keeping a trailing ion in the cathode buffer and the resolving gel and showed that this continuous stacking of SDS was efficiently prevented. In our hands, this PAGE system however did not improve the resolution of deamidated Bcl-xL compared to ours (data not shown). So, building on their work, we designed a continuous PAGE set up keeping a unique running buffer both in the anode and cathode tanks, that contained Glycinate as a trailing ion. We maintained Taurine and Glycinate as separating trailing ions in the resolving gel, but we combined imidazole and Tris as counter ions in the stacking gel. Compared to the resolution of deamidated Bcl-xL obtained with our previous gels (Fig. 2A), this new composition produced a modification in the mobility of leading and trailing ions that proved conducive to a better stacking/destacking effect of the proteins (Fig. 2B). SDS was clearly destacked from the proteins since an improved electrofocusing of the deamidated forms of Bcl-xL could be achieved (compare Fig. 2B and Fig. 2A, compare also Fig. 2C and suppl Fig. 1A). 


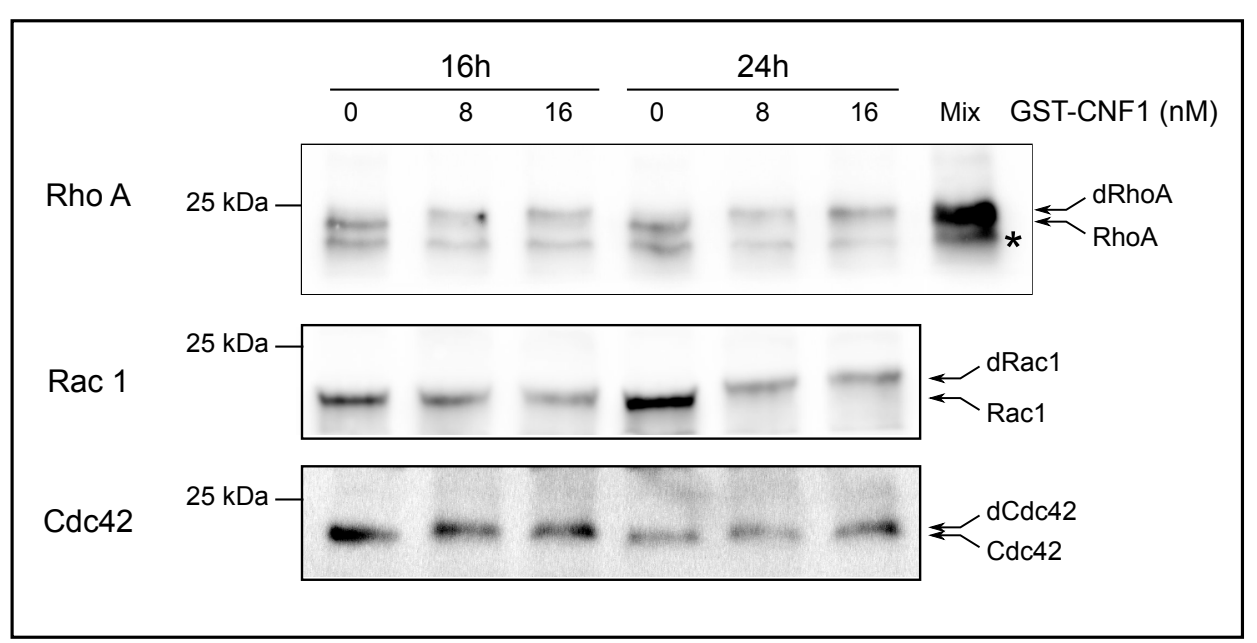

Fig. 1. Gln deamidation of RhoA, Rac1 and Cdc42 can be detected by migration shift on PAGE: HCT116 cells were seeded at 800,000 cells per well in 6-cm dishes and once they attached, $16 \mathrm{~h}$ or 24 h-treatment with $8 \mathrm{nM}$ or $16 \mathrm{nM} \mathrm{GST}$ CNF1 were performed in the presence of $20 \mu \mathrm{M}$ MG132 to prevent proteasomal degradation. Total proteins were extracted and $25 \mu \mathrm{g}$ separated on $15 \%$ Taurine/Glycinate gels. Immundetection of RhoA, Rac1 and Cdc42 is shown. The experiment was repeated 8 times. For RhoA, in the last lane, $15 \mu \mathrm{g}$ of proteins extracted from untreated cells were mixed with $15 \mu \mathrm{g}$ from cells treated with $16 \mathrm{nM}$ GST-CNF1 for $24 \mathrm{~h}$. (*) unspecific band.

\subsection{Comparison of Bcl-xL stability in different solutions}

We decided to use this improved resolution to compare the catalytic rates of Bcl-xL deamidation in various solutions. We selected the compositions, $\mathrm{pH}$ and ionic strengths that had been shown to accelerate efficiently deamidation rates of peptides in different studies [16].

Bcl-xL deamidation profile was analyzed on gels as a function of time of incubation of the recombinant protein at $37^{\circ} \mathrm{C}$, either in the storage buffer $(\mathrm{pH}=8)$ or in the alkaline solutions listed in Table 1 . On each gel of Fig. 2C, the migration distance of untreated Bcl-xL was used as a negative control for deamidation, while the mutant of Bcl-xL where Asn52 and 66 have been replaced by Asp residues (noted N52D/N66D) was used to show the migration distance of doubly deamidated Bcl-xL. Fig. 2C shows the basal deamidation rate of $\mathrm{Bcl}-\mathrm{xL}$ in the storage buffer ( $\mathrm{pH}=8, I=0.45)$ at $37^{\circ} \mathrm{C}$ : the amount of native Bcl-xL remained constant until $8 \mathrm{~h}$, and the monodeamidated form increased at the expense of native Bcl-xL as of $8 \mathrm{~h}$ of incubation and up to $48 \mathrm{~h}$. Doubly deamidated Bcl-xL could be detected at $24 \mathrm{~h}$ and increased until $48 \mathrm{~h}$. Of note, under these conditions, only a partial deamidation of Bcl-xL could be achieved because native and monodeamidated Bcl-xL were still detected at the end of the experiment.

Bcl-xL was then exposed to deamidation solutions previously described and used on peptides. The deamidation profile in the solution containing the strong base $\mathrm{NaOH}(\mathrm{pH}=8, I=0.46)$ was indistinguishable from that in the storage buffer. Likewise, when Tris or Glycine were added in the solution and $\mathrm{pH}$ made slightly more alkaline $(\mathrm{pH} \sim$ 8.5) Bcl-xL deamidation profile at $37{ }^{\circ} \mathrm{C}$ was only marginally accelerated compared to the storage solution: in both conditions, native Bcl-xL was no longer visible at $48 \mathrm{~h}$ of treatment, but double deamidation was not complete. Interestingly, in the presence of $\mathrm{NH}_{4} \mathrm{OH}$ and in a more alkaline environment $(\mathrm{pH}=10, I=0.45), \mathrm{Bcl}-\mathrm{xL}$ deamidation was rapid and complete: native Bcl-xL could no longer be detected after only $4 \mathrm{~h}$ of incubation, and complete conversion into doubly deamidated Bcl-xL was achieved in $8 \mathrm{~h}$. Finally, the condition where phosphate was used as ion buffer and ionic strength increased $(I=0.56)$ showed that Bcl-xL deamidation was complete after $24 \mathrm{~h}$ of treatment.

The ion buffers used in the experiments above had previously been tested on peptides [16], and the study already highlighted $\mathrm{NH}_{4} \mathrm{OH}$ and phosphate as potent deamidation catalysts. Unlike peptides however, whole proteins are susceptible to 3D structural changes that can also account for a modification in the deamidation rate. We therefore investigated whether $\mathrm{NH}_{4} \mathrm{OH}$ treatment (which gave the most compelling effects on $\mathrm{Bcl}-\mathrm{xL}$ deamidation rate) induced a massive structural rearrangement. Circular dichroism spectra allowed us to rule out this hypothesis (Suppl Fig.2), which indicates instead that $\mathrm{NH}_{4} \mathrm{OH}$ accelerates the reaction catalysis.
In conclusion, this set of experiments shows that the electrophoretic method described here allowed to screen at once the time-course of Bcl$\mathrm{xL}$ deamidation in various conditions of $\mathrm{pH}$, ionic strength and buffer ions. A proper storage buffer for a protein is one providing long-time stability. Bcl-xL requires high salt concentration for its proper folding ( $\sim 450 \mathrm{mM}$ salt). The experiments presented here helped us determine that Bcl-xL was more susceptible to deamidation when the ionic strength was increased to $I=0.56$, and that $\mathrm{NH}_{4} \mathrm{OH}$ and phosphate ion buffers should be avoided in the storage solution in order to maintain deamidation as low as possible.

\subsection{Comparison of Calmodulin stability in different solutions}

We next set out to investigate whether the same analysis could be applied to another poly-deamidable protein, namely Calmodulin. This protein acts as a calcium-binding messenger in cells, and once loaded with $\mathrm{Ca}^{2+}$, it interacts with many target proteins in what is known as the calcium signal transduction pathway. The deamidation sites of this 16.7 $\mathrm{kDa}$ protein have been characterized by the Aswad lab [34]. Two Asn residues (60 and 97), located in distinct $\mathrm{Ca}^{2+}$ binding sites have been shown to deamidate. It has been proposed that calcium binding prevents deamidation while EDTA facilitates time-dependent or $\mathrm{pH}$-accelerated deamidation [13].

We used recombinant human Calmodulin and monitored the time course of its deamidation at $37^{\circ} \mathrm{C}$ in the presence of the same ion buffers used with Bcl-xL. In each solution, Calmodulin was either left untreated (NT), or incubated with EDTA or $\mathrm{Ca}^{2+}$. On Fig. 3A, our original mini-gels using Taurine/Glycinate as trailing ions highlighted that Tris and $\mathrm{NaOH}$ did not produce any significant change in the migration profiles of Calmodulin revealed by Coomassie blue staining. Unlike Bcl-xL however, it seemed that $\mathrm{NH}_{4} \mathrm{OH}$ did not catalyze Calmodulin deamidation. Phosphate did produce a time-dependent modification of the protein that resulted in slower migrating forms. Of note, the difference was visible only when the protein was loaded with $\mathrm{Ca}^{2+}$.

The very same samples were analyzed on gels where imidazole was added as counter ion in the stacking gel (Fig. 3B). A compelling improved focusing could be observed, as the smearing effect due to SDS stacking was prevented. When compared to the protein incubated in the storage solution ( $\mathrm{pH} 6.7, I=0.5$ ) the absence of catalysis by Tris and $\mathrm{NaOH}$ on Calmodulin deamidation was confirmed. But two striking differences were observed compared to Fig. 3A: (1) an effect of $\mathrm{NH}_{4} \mathrm{OH}$ became visible when the protein had been incubated for $16 \mathrm{~h}$ in the presence of EDTA. However, $\mathrm{Ca}^{2+}$ loaded samples still did not show any deamidation; (2) the time-dependent modification produced by phosphate was now detected both when the protein was incubated with EDTA and $\mathrm{Ca}^{2+}$. It should be noted that when present in the samples, 


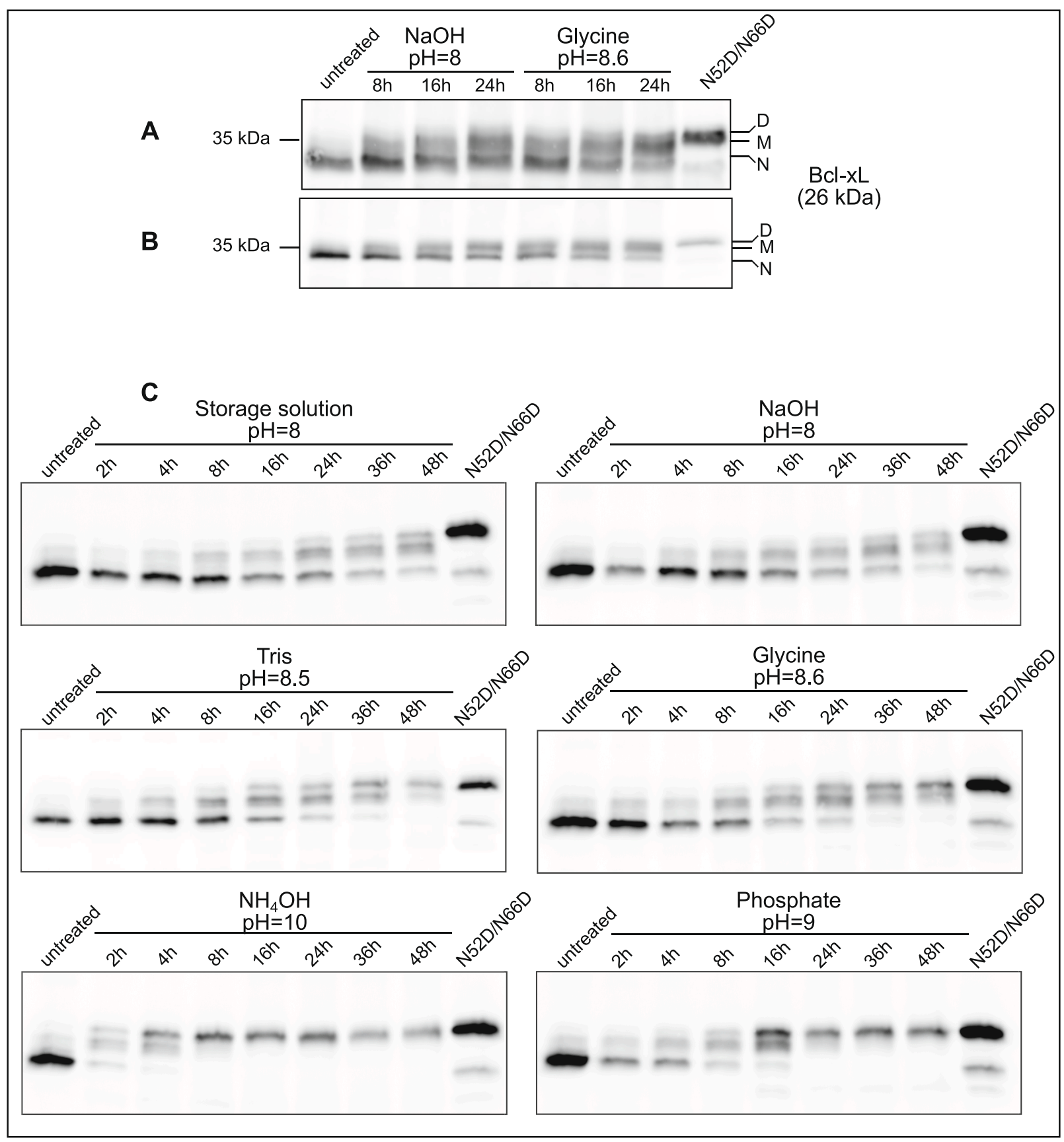

Fig. 2. Imidazole improves the focusing of deamidated forms of Bcl-xL: Purified native Bcl-xL was treated for the indicated times at $37^{\circ} \mathrm{C}$ in different deamidation solutions, or left untreated. (A) Proteins were separated on $12 \%$ gels using Taurine/Glycinate as trailing ions. (B and C) Proteins were separated on modified $12 \%$ (B) and 15\% (C) Taurine/Glycinate gels including imidazole in the stacking gel. Immunodetection of Bcl-xL was performed. Note that in B, the Image J algorithm "Straighten" was used to assist a better appraisal of the migration shift between native and deamidated Bcl-xL. The original image can be found in supplemental data. Untreated Bcl-xL runs as the native form (N), the mutant Bcl-xL N52D/N66D was used to indicate the migration distance of doubly deamidated BcL-xL (D). (M) indicates the migration distance of N52 monodeamidated Bcl-xL. The experiment was repeated at least 8 times.

negatively charged EDTA induced a retardation in the migration of Calmodulin compared to NT samples. Because of this shift, deamidated species span a lesser zone than $\mathrm{Ca}^{2+}$ loaded samples. Importantly, this EDTA-driven shift is not a sign of deamidation as testified by the comparable amount of IsoAsp residues quantified in $\mathrm{Ca}^{2+}$ and EDTA treated samples at time 0 (Fig. 3C). We performed a quantification of IsoAsp residues produced during the course of Calmodulin incubation with phosphate to substantiate that the slow migrating bands represented deamidated forms of Calmodulin. Fig. 3C confirmed that increasing amounts of IsoAsp could be detected with time, both in EDTA and $\mathrm{Ca}^{2+}$ containing samples.
Altogether, Fig. 3 shows that the improved focusing provided by imidazole revealed migration differences that were previously obscured by the stacking of SDS; the new gel composition described here was instrumental to reveal that in the case of Calmodulin, phosphate was a better deamidation catalyst than $\mathrm{NH}_{4} \mathrm{OH}$. In other words, Phosphate should be avoided in the storage buffer of Calmodulin. Other noticeable differences with Bcl-xL were (1) that up to $48 \mathrm{~h}$ of incubation at $37{ }^{\circ} \mathrm{C}$ Calmodulin did not deamidate in its storage solution in spite of a high ionic strength, and (2) that regardless of the catalyst, only a partial deamidation of Calmodulin could be obtained even after $48 \mathrm{~h}$ of incubation. 


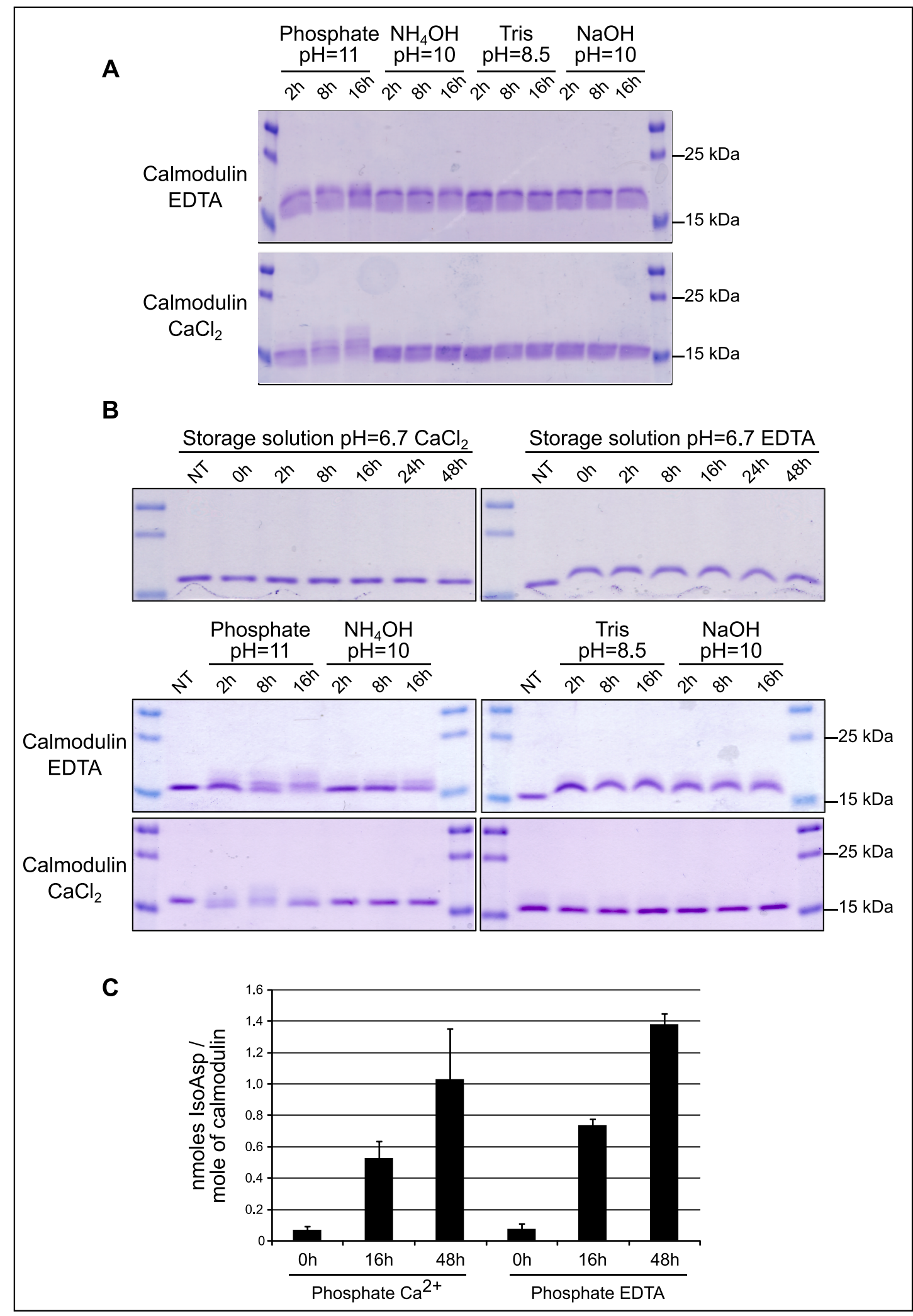

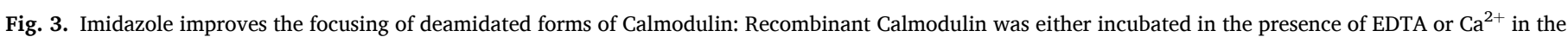
indicated deamidation solution at $37^{\circ} \mathrm{C}$. (A) Proteins were separated on $12 \%$ gels containing Taurine/Glycinate as trailing ions (described in Bobo et al., 2019). Gels were stained with Coomassie Blue. (B) Proteins were separated on $12 \%$ acrylamide gels that contained Tris and imidazole in the stacking, and that used Taurine/ Glycinate as trailing ions. Gels were stained with Coomassie Blue. Independent experiments were repeated at least 5 times. (C) Quantification of the IsoAsp residues formed in Calmodulin upon incubation in Phosphate buffer with the IsoQuant-Glo kit. Two independent experiments were performed, and SD is shown ( $\mathrm{n}=3$ ). (For interpretation of the references to colour in this figure legend, the reader is referred to the web version of this article.) 


\section{Discussion}

We describe here the use of 1D continuous PAGE formulations to provide a rapid, affordable and effective detection of five different deamidated proteins in the range of $15-40 \mathrm{kDa}$. We had previously shown that using Taurine/Glycinate as trailing ions in the resolving gels was more efficient than standard SDS-PAGE to monitor on mini-gels the sequential Asn deamidation of the oncogene Bcl-xL [23]. We show here that the same formulation can be used to detect Gln deamidation in other proteins, like the small GTPase RhoA and Rac1. This is a significant advance since the ability of SDS-PAGE to highlight RhoA migration shifts was disputed between early reports $[29,30]$ and more recent papers $[25,35]$. However, when we applied this method to other deamidable proteins like Calmodulin (Fig. 3A), the results were not compelling enough, as the migration appeared fuzzy. This is due to the stacking of SDS built during electrophoresis between the leading ion and the trailing ion. We describe here that including imidazole along with Tris as counter ions in the stacking gel is sufficient to efficiently destack SDS and allow a better resolution of proteins like Bcl-xL and Calmodulin in the range of $15-40 \mathrm{kDa}$. Of note, this imidazole modification did not increase the migration shift of Gln deamidated GTPases (not shown) because Taurine/Glycinate gels already provided well focused bands. For further development of SDS destacking, it would be interesting to test whether other counter ions might also provide the same effect: one immediate candidate would be histidine because of its structural resemblance with imidazole although their $\mathrm{pKa}$ are quite different $\left(\mathrm{pKa}_{2}\right.$ Histidine $=6.0$ versus $\mathrm{pKa}_{\text {imidazole }}=6.95$ ); other buffer species could also be tested like MES (pKa $=6.15$ ) and MOPS ( $\mathrm{pKa}=7.15$ ).

Easy discrimination of discrete deamidated forms vs non-deamidated proteins is sought-after, and we show here a direct application of our 1D continuous gel formulation to assay the stability of Bcl-xL and Calmodulin in various solutions. A first striking observation was on the difference in the stability of both proteins in their respective storage solution. Calmodulin was remarkably stable over time at $37{ }^{\circ} \mathrm{C}$ as indicated by its appearance on gels, and as indicated by the quantity of IsoAsp detected in the untreated protein. Conversely, Bcl-xL appeared exquisitely prone to deamidation in its storage solution. Even though high salts are needed to maintain this protein soluble in the long term, our study underscores that this requirement is a liability when it comes to protein stability. Therefore caution must be paid to keep the temperature as low as possible to prevent Bcl-xL deamidation.

When we investigated the catalytic effect of $\mathrm{pH}$ and different ions on the deamidation rates of Bcl-xL and Calmodulin, we succeeded in visualizing the sequential deamidation of both proteins. Of note, the ionic strength of solutions was not the same for Bcl-xL and Calmodulin (except in the storage solutions, where $I \sim 0.5$ ), probably accounting for some differences. If $\mathrm{NH}_{4} \mathrm{OH}$ was the most efficient catalyst for Bcl-xL and produced rapidly the doubly deamidated form, phosphate operated as the best catalyst for Camodulin, but complete deamidation was not obtained even for protracted times of incubation. Also, while Tris catalyzed at least a partial deamidation of Bcl-xL over the time-frame chosen, Calmodulin deamidation was essentially impervious to this treatment. Further work will be needed to explore deamidation kinetics of both proteins in identical solutions.

As of 1949, Gilbert et al. had established, on free glutamine deamidation, that phosphate was a better catalyst than borate, arsenate and sulfate [36]. However, subsequent studies on model peptides had shown conflicting results on the effect of various catalysts on Asn and Gln deamidation [14-16,18]. Our data, obtained on whole proteins suggest that these conflicting reports actually merely underscored that each protein behaves differently toward a given catalyst; it appears that the ability to form a transition complex to facilitate rate limiting step of the reaction (the formation of the imide intermediate) is specific to each protein/catalyst pair. As the $\mathrm{n}+1$ amino acid is involved in the formation of the cyclic imide intermediate, it is not counter-intuitive that each deamidable site in a given protein posses specific physico-chemical properties that react more or less efficiently with a catalyst for the formation of a transition complex [9].

Calmodulin deamidation and the effect of calcium or EDTA on the reaction rate were previously investigated, mostly by the Aswad lab [13] and the Clarke lab [37]. Attempts were made to use electrophoresis to discriminate unmodified and deamidated Calmodulin: classical SDSPAGE did not show any difference (see Fig. 2a in [38]); nondenaturing gels containing EDTA helped observing migration shifts discriminating native and deamidated forms of Calmodulin, but the separation was slow and required 8-12 h [20]. In the rapid PAGE minigel system described here, the presence of imidazole in the stacking gel was critical to reveal deamidated states of Calmodulin incubated with EDTA that did not appear without imidazole. The quantification of IsoAsp in phosphate treated samples confirmed that the slower migrating species corresponded to deamidated forms of Calmodulin, and concur with results published elsewhere [39]. In the end, we confirmed that Calmodulin deamidation induced at alkaline $\mathrm{pH}$ in the presence of phosphate was visible whether the protein was loaded with $\mathrm{Ca}^{2+}$ or not. This is in keeping with the Aswad work showing that $\mathrm{Ca}^{2+}$ protective effect toward deamidation was only observed when in vitro deamidation is performed at physiological $\mathrm{pH}$ [13].

Historically, very comprehensive analyses have been carried out on peptides to determine the factors influencing deamidation (for review, see [12]). All the data have been computed and algorithms developed to predict quite accurately the probability for Asn or Gln residues to deamidate in whole proteins [11]. However, our previous work on Bcl-xL $[8,22,23]$, and the data presented here illustrate that a case-by-case analysis of whole proteins and their susceptibility to deamidation should be sought. The availability of an electrophoretic method as simple as what we described here can be predicted to find at least two major applications: one is to screen the better suited buffer formulation for protein long-term storage, and the other is to make deamidation more accessible to labs that do not have easy access to highly specialized and methods.

Regarding the former, separation methods using reverse phase chromatography or capillary isoelectrofocusing can only process one sample or condition at a time. The main advantage of the electrophoretic method presented here is to allow to screen multiple samples or conditions at a time, and to tailor to each protein the choice of buffer ions, $\mathrm{pH}$ and ionic strength to limit deamidation.

Regarding the latter, other biochemical methods are undeniably far more sensitive or far more precise to assign the residues eligible for deamidation and even separate Asp and Iso-Asp. It is the case for mass spectrometry analyses (reviewed in this Special Issue) or reverse phase chromatography, or capillary isoelectrofocusing, which will in the end be mandatory to investigate deamidation in depth. Not all laboratory can easily resort to these techniques. PAGE however is certainly one of the most widely used method. Provided that the candidate protein can be detected by western blot, there is no particular need regarding the complexity of the sample, as only a few micrograms of total cell extracts can suffice. Even if hundreds of proteins are known to deamidated in eukaryotic cells, the question is often dismissed by researchers by lack of lay techniques to address deamidation rapidly. Being able to implement techniques as easy as 1D PAGE to detect protein deamidation will definitely be a major asset to this end, even if the limitation of the technique presented here is that some deamidation-related migration shifts might remain inconspicuous or extremely slight as was the case here for Cdc42. But most of the techniques used to date are designed either to predict a deamidation score for Asn and Gln in proteins when deamidation has not been proven yet, or to specify the residues and byproducts rates when a protein is known to deamidate. The missing link in this flowchart is the screening of potentially deamidated proteins. This is tackled by the present study. 


\section{Declaration of Competing Interest}

The authors declare that they have no known competing financial interests or personal relationships that could have appeared to influence the work reported in this paper.

\section{Acknowledgements}

This work was supported by the Centre National de la Recherche Scientifique (CNRS, FRANCE) and Université de Bordeaux, FRANCE (to UMR 5095). M.P. was supported by Ligue Nationale Contre le Cancer (FRANCE) and expresses her gratitude to the Comités des Landes, Charente-Maritime and Dordogne for their ongoing support. We thank D. Arma for her help in the purification of GST-CNF1.

The Image J "Straighten" algorithm is described in Kocsis, E., Trus, B. L., Steer, C.J., Bisher, M.E. and Steven, A.C (1991) J. Struct. Biol. 107, 614.

\section{Appendix A. Supplementary data}

Supplementary data to this article can be found online at https://doi. org/10.1016/j.ymeth.2021.03.002.

\section{References}

[1] N.E. Robinson, A.B. Robinson, Molecular Clocks: Deamidation of Asparaginyl and Glutaminyl Residues in Peptides and Proteins, Althouse Press, 2004.

[2] J.J. Cournoyer, P.B. O'Connor, Chapter 16 Analysis of Deamidation in Proteins, in: J.P. Whitelegge (Ed.), Comprehensive Analytical Chemistry, Elsevier, 2008: pp. 375-410. https://doi.org/10.1016/S0166-526X(08)00216-X.

[3] M. Barbariga, F. Curnis, A. Andolfo, A. Zanardi, M. Lazzaro, A. Conti, G. Magnani, M.A. Volontè, L. Ferrari, G. Comi, A. Corti, M. Alessio, Ceruloplasmin functional changes in Parkinson's disease-cerebrospinal fluid, Mol. Neurodegeneration 10 (2015) 1-12, https://doi.org/10.1186/s13024-015-0055-2.

[4] A. Zanardi, M. Alessio, Ceruloplasmin deamidation in neurodegeneration: from loss to gain of function, Int. J. Mol. Sci. 22 (2021) 663, https://doi.org/10.3390/ ijms22020663.

[5] S.S. Adav, S.K. Sze, Insight of brain degenerative protein modifications in the pathology of neurodegeneration and dementia by proteomic profiling, Mol. Brain 9 (2016) 1-22, https://doi.org/10.1186/s13041-016-0272-9.

[6] K.J. Lampi, P.A. Wilmarth, M.R. Murray, L.L. David, Lens $\beta$-crystallins: The role of deamidation and related modifications in aging and cataract, Prog. Biophys. Mol. Biol. 115 (2014) 21-31, https://doi.org/10.1016/j.pbiomolbio.2014.02.004.

[7] F.S. Van Kleef, W.W. De Jong, H.J. Hoenders, Stepwise degradations and deamidation of the eye lens protein alpha-crystallin in ageing, Nature 258 (1975) 264-266.

[8] F. Beaumatin, M. El Dhaybi, C. Bobo, M. Verdier, M. Priault, Bcl-xL deamidation and cancer: Charting the fame trajectories of legitimate child and hidden siblings, Biochim. Biophys. Acta 1864 (2017), https://doi.org/10.1016/j bbamcr.2017.06.012.

[9] F. Beaumatin, M. El Dhaybi, C. Bobo, M. Verdier, M. Priault, Corrigendum to "Bc xL deamidation and cancer: Charting the fame trajectories of legitimate child and hidden siblings." [Biochim. Biophys. Acta 1864/10 (2017) 1734-1745], Biochim Biophys Acta Mol Cell Res. 1865 (2018) 542-543. https://doi.org/10.1016/j. bbamcr.2018.01.002.

[10] N.E. Robinson, Z.W. Robinson, B.R. Robinson, A.L. Robinson, J.A. Robinson, M. L. Robinson, A.B. Robinson, Structure-dependent nonenzymatic deamidation of glutaminyl and asparaginyl pentapeptides, J. Peptide Res. 63 (2004) 426-436, https://doi.org/10.1111/j.1399-3011.2004.00151.x.

[11] N.E. Robinson, A.B. Robinson, Deamidation of human proteins, PNAS 98 (2001) 12409-12413, https://doi.org/10.1073/pnas.221463198.

[12] A.B. Robinson, C.J. Rudd, Deamidation of glutaminyl and asparaginyl residues in peptides and proteins, in: B.L. Horecker, E.R. Stadtman (Eds.), Current Topics in Cellular Regulation, Academic Press, 1974, pp. 247-295, https://doi.org/10.1016/ B978-0-12-152808-9.50013-4.

[13] B.A. Johnson, J.M. Shirokawa, D.W. Aswad, Deamidation of calmodulin at neutra and alkaline pH: Quantitative relationships between ammonia loss and the susceptibility of calmodulin to modification by protein carboxyl methyltransferase, Arch. Biochem. Biophys. 268 (1989) 276-286, https://doi.org/10.1016/00039861(89)90589-4.

[14] S. Capasso, L. Mazzarella, A. Zagari, Deamidation via cyclic imide of asparaginyl peptides: dependence on salts, buffers and organic solvents, Pept. Res. 4 (1991) 234-238.

[15] J.W. Scotchler, A.B. Robinson, Deamidation of glutaminyl residues: Dependence on $\mathrm{pH}$, temperature, and ionic strength, Anal. Biochem. 59 (1974) 319-322, https:// doi.org/10.1016/0003-2697(74)90040-2.
[16] K. Patel, R.T. Borchardt, Chemical pathways of peptide degradation. II. Kinetics of deamidation of an asparaginyl residue in a model hexapeptide, Pharm. Res. 7 (1990) 703-711.

[17] J.H. McKerrow, A.B. Robinson, Primary sequence dependence of the deamidation of rabbit muscle aldolase, Science. 183 (1974), 85-85 10.1126/science: 183.4120 .85 .

[18] R. Tyler-Cross, V. Schirch, Effects of amino acid sequence, buffers, and ionic strength on the rate and mechanism of deamidation of asparagine residues in small, Peptides 266 (1991) 22549-22556.

[19] K. Faserl, B. Sarg, V. Maurer, H.H. Lindner, Exploiting charge differences for the analysis of challenging post-translational modifications by capillary electrophoresis-mass spectrometry, J. Chromatogr. A 1498 (2017) 215-223, https://doi.org/10.1016/j.chroma.2017.01.086.

[20] B.A. Johnson, E.L. Langmack, D.W. Aswad, Partial repair of deamidation-damaged calmodulin by protein carboxyl methyltransferase, J. Biol. Chem. 262 (1987) 12283-12287.

[21] N. Bae, J.-W. Yang, H. Sitte, A. Pollak, J. Marquez, G. Lubec, An electrophoretic approach to screen for glutamine deamidation, Anal. Biochem. 428 (2012) 1-3, https://doi.org/10.1016/j.ab.2012.05.016.

[22] F. Beaumatin, M.E. Dhaybi, J.-P. Lasserre, B. Salin, M.P. Moyer, M. Verdier, S. Manon, M. Priault, N52 monodeamidated Bcl-x L shows impaired oncogenic properties in vivo and in vitro, Oncotarget 7 (2016) 17129-17143. https://doi. org $/ 10.18632 /$ oncotarget.7938.

[23] C. Bobo, C. Céré, M. Dufossée, A. Dautant, V. Moreau, S. Manon, F. Beaumatin, M. Priault, Improved electrophoretic separation to assist the monitoring of Bcl-xL post-translational modifications, Int. J. Mol. Sci. 20 (2019) 5571, https://doi.org/ 10.3390/ijms20225571.

[24] M. Lerm, M. Pop, G. Fritz, K. Aktories, G. Schmidt, Proteasomal degradation of cytotoxic necrotizing factor 1-Activated Rac, Infect. Immunity 70 (2002) 4053-4058, https://doi.org/10.1128/IAI.70.8.4053-4058.2002.

[25] V. Moreau, F. Tatin, C. Varon, E. Génot, Actin can reorganize into podosomes in aortic endothelial cells, a process controlled by Cdc42 and RhoA, Mole. Cell. Biol. 23 (2003) 6809-6822, https://doi.org/10.1128/MCB.23.19.6809-6822.2003.

[26] M.-L. Diebold, S. Fribourg, M. Koch, T. Metzger, C. Romier, Deciphering correct strategies for multiprotein complex assembly by co-expression: Application to complexes as large as the histone octamer, J. Struct. Biol. 175 (2011) 178-188, https://doi.org/10.1016/j.jsb:2011.02.001.

[27] Y. Yao, F.M. Marassi, Reconstitution and Characterization of BCL-2 Family Proteins in Lipid Bilayer Nanodiscs, in: E. Gavathiotis (Ed.), BCL-2 Family Proteins, Springer, New York, New York, NY, 2019, pp. 233-246, https://doi.org/10.1007/ 978-1-4939-8861-7 16.

[28] Y. Yao, D. Nisan, L.M. Fujimoto, A. Antignani, A. Barnes, N. Tjandra, R.J. Youle, F. M. Marassi, Characterization of the membrane-inserted C-terminus of cytoprotective BCL-XL, Protein Expression Purif. 122 (2016) 56-63, https://doi. org/10.1016/j.pep.2016.02.010.

[29] G. Schmidt, P. Sehr, M. Wilm, J. Selzer, M. Mann, K. Aktories, Gln 63 of Rho is deamidated by Escherichia coli cytotoxic necrotizing factor-1, Nature 387 (1997) 725-729, https://doi.org/10.1038/42735.

[30] G. Flatau, E. Lemichez, M. Gauthier, P. Chardin, S. Paris, C. Fiorentini, P. Boquet, Toxin-induced activation of the $\mathrm{G}$ protein $\mathrm{p} 21$ Rho by deamidation of glutamine, Nature 387 (1997) 729-733, https://doi.org/10.1038/42743.

[31] A. Doye, A. Mettouchi, G. Bossis, R. Clément, C. Buisson-Touati, G. Flatau, L. Gagnoux, M. Piechaczyk, P. Boquet, E. Lemichez, CNF1 Exploits the UbiquitinProteasome Machinery to Restrict Rho GTPase Activation for Bacterial Host Cell Invasion, Cell. 111 (2002) 553-564, https://doi.org/10.1016/S0092-8674(02) 01132-7.

[32] S.W. Muchmore, M. Sattler, H. Liang, R.P. Meadows, J.E. Harlan, H.S. Yoon, D. Nettesheim, B.S. Chang, C.B. Thompson, S.-L. Wong, S.-C. Ng, S.W. Fesik, X-ray and NMR structure of human Bcl-xL, an inhibitor of programmed cell death, Nature 381 (1996) 335-341, https://doi.org/10.1038/381335a0.

[33] I.P. Maly, C. Nitsch, SDS disc electrophoresis of proteins in homogeneous, lowconcentrated polyacrylamide gels, Electrophoresis 28 (2007) 1508-1513, https:// doi.org/10.1002/elps.200600688.

[34] S.M. Potter, W.J. Henzel, D.W. Aswad, In vitro aging of calmodulin generates isoaspartate at multiple Asn-Gly and Asp-Gly sites in calcium-binding domains II, III, and IV, Protein Sci. 2 (1993) 1648-1663.

[35] M. Musilli, M.T. Ciotti, M. Pieri, A. Martino, S. Borrelli, V. Dinallo, G. Diana, Therapeutic effects of the Rho GTPase modulator CNF1 in a model of Parkinson's disease, Neuropharmacology 109 (2016) 357-365, https://doi.org/10.1016/j. neuropharm.2016.06.016.

[36] J.B. Gilbert, V.E. Price, J.P. Greenstein, Effect of anions on the non-enzymatic desamidation of glutamine, J. Biol. Chem. 180 (1949) 209-218.

[37] I.M. Ota, S. Clarke, Calcium affects the spontaneous degradation of aspartyl/ asparaginyl residues in calmodulin, Biochemistry 28 (1989) 4020-4027, https:// doi.org/10.1021/bi00435a058.

[38] R.R. Desrosiers, E.A. Romanik, C.M. O'Connor, Selective carboxyl methylation of structurally altered calmodulins in Xenopus oocytes, J. Biol. Chem. 265 (1990) 21368-21374.

[39] K. Hsiao, J. Alves, R. Patel, M. Adams, V. Nashine, S. Goueli, A high-throughput bioluminescent assay to monitor the deamidation of asparagine and isomerization of aspartate residues in therapeutic proteins and antibodies, J. Pharm. Sci. 106 (2017) 1528-1537, https://doi.org/10.1016/j.xphs.2017.02.022. 